\title{
The Influencing Factors on Impulse Buying Behavior of Consumers under the Mode of Hunger Marketing in Live Commerce
}

\author{
Zhenfang Zhang, Nan Zhang and Jiguang Wang *(i)
}

check for updates

Citation: Zhang, Z.; Zhang, N.;

Wang, J. The Influencing Factors on Impulse Buying Behavior of Consumers under the Mode of Hunger Marketing in Live Commerce. Sustainability 2022, 14, 2122. https://doi.org/10.3390/ su14042122

Academic Editors: Iwona Zdonek and Adam R. Szromek

Received: 11 January 2022

Accepted: 9 February 2022

Published: 13 February 2022

Publisher's Note: MDPI stays neutral with regard to jurisdictional claims in published maps and institutional affiliations.

Copyright: (c) 2022 by the authors. Licensee MDPI, Basel, Switzerland. This article is an open access article distributed under the terms and conditions of the Creative Commons Attribution (CC BY) license (https:/ / creativecommons.org/licenses/by/ $4.0 /)$.

\author{
School of Economics and Management, Shanxi University, Taiyuan 030006, China; \\ zhangzhenfang@sxu.edu.cn (Z.Z.); zn17835396231@163.com (N.Z.) \\ * Correspondence: wangjg@sxu.edu.cn
}

\begin{abstract}
The sustainability of live commerce is closely dependent on the impulse buying behavior of consumers because of its live characters compared to the traditional e-commerce mode. Hunger marketing is a widely adopted mode in live commerce, however, the influencing factors on impulse buying behavior of consumers under the mode of hunger marketing in live commerce is currently lacking. Here, based on SOR theory, we carefully studied how external stimulus variables (anchor characteristics, online comments, logistics service quality, promotion incentive information, and promotional time limit) affected consumers' impulse buying behavior under the inner mechanism reaction factors (perceived trust and perceived value). By collecting questionnaires from 533 Chinese online consumers, we processed these data using SPSS23.0 and analyzed them using the structural equation model (SEM) generated by AMOS 25.0. The results showed that extrinsic stimulus variables (except for the promotional time limit variable) have significant positive effects on impulse buying behavior through partial or total positive effects on intrinsic mechanisms. We analyzed the reasons for all these results in detail, and thought the reason that the promotional time limit did not have a significant impact on the perceived value might be due to the rapid increase in the frequency of live commerce. Moreover, we also put forward the suggestions on the basis of these influencing factors to improve the sustainable development of live commerce.
\end{abstract}

Keywords: live commerce; hunger marketing; perceived trust; perceived value; impulse buying behavior

\section{Introduction}

The sustainable development of e-commerce requires enterprises to innovate marketing forms and models constantly. There are many problems in the traditional retail industry, such as high cost, low realizable profit, a poor precipitation effect and a small radiation range. With the rapid development of network technology and mobile terminals in recent years, the mode of live commerce provides new opportunities for the sustainable and healthy development of e-commerce. Live commerce is a new type of social interaction platform that provides a way to promote sustainable product consumption online [1]. It breaks through the limitations of time and space, and creates a refined live commerce marketing system of "private sphere + retail + full scene" for consumers [2]. This model combines a stereo environment, preferential price, diversified products, fast payment methods, convenient logistics services and other aspects, giving consumers a strong sense of presence, and stimulating consumers' purchase intention, thus driving product sales and obtaining rich profits. 2016 was the first "Year of Live Commerce" in China [3]. The ability of e-commerce platforms to cash in goods has been truly realized since the rise of the "Double 11" online shopping festival in 2017. Since the outbreak of the epidemic in 2020, offline consumer demand has been suppressed, making the facilitating role of online live streaming of goods more obvious. How to maintain the sustainable development of live commerce is a problem that should be paid attention to at present, and this requires the common attention of both industry practitioners and academia. 
It can be said that live commerce as an emerging business model not only brings huge profits but also attracts a large amount of user traffic. Although it is difficult to find a replacement in a short period of time, live commerce has also encountered some shortcomings while prospering. Its sustainable development has become the focus of attention from all walks of life, and only a profound analysis of the problems aimed at developing a sound operation mechanism that plans the right direction of development will help with these issues. Live commerce has a high acceptance among contemporary consumer groups, so research based on the perspective of users is more conducive to revealing the industry's shortcomings, helping it break through the bottleneck period and achieve long-term sustainable development.

In order to maintain the sustainable development of e-commerce live commerce, it has become a hot topic to study the purchasing behavior of consumers. Through situational experiments and relevant secondary data, Huang et al. found that the recommendation of hedonic products by reputable anchors can help trigger the recognition mechanism of consumers and improve their purchase intention and product sales [4]. Yan et al., (2021) believed that the popularity of anchors, interactivity and personalized service in live commerce had a positive impact on consumers' purchasing behavior to varying degrees [5]. In this process, consumers' perceived value plays a mediating role between the characteristics of live commerce and purchasing behavior. Liu et al., (2013) proved that commodity availability and website ease of use in online shopping features significantly affect consumers' visual attractiveness, which in turn produces instant satisfaction and influences consumers impulse buying [6]. Zheng (2021) found in his research that the higher the degree of interaction with users in the broadcast room, the more likely users will have flow experience and the more likely they will form cross-purchase intention [7].

Previous research has shown that different marketing models can lead to different purchasing behaviors of consumers. In the traditional marketing mode, consumers' purchasing behavior is attracted by advertising marketing, direct marketing, and other strategies [8]. For live commerce, there are also various types of goods. For example, in the traditional ecommerce marketing model, some brands simply introduce their products for the purpose of doing so. Specifically, the anchors show, explain and try on the products in a full range in the form of live commerce so as to deepen consumers' understanding of the products and brands. However, there are no preferential activities. In this single mode, it is difficult to arouse consumers' shopping intentions. In addition, when e-retailers adopt the influence of marketing incentives, situational influence and individual characteristics, live commerce is more likely to trigger consumers' impulsive buying behavior [9]. It can be seen that under different sales modes, consumers' purchasing behaviors are very different, so it is more accurate to study the purchasing behaviors under specific modes.

Currently, the single live commerce mode has gradually entered a soft state. In order to break through the sales bottleneck, "hunger marketing" has become a common marketing mode in live commerce. The "hunger marketing" strategy comes from the "utility theory" in economic theory, through making consumers feel satisfied [10] in order to build a solid psychological foundation for marketing. Hunger marketing strategy, in the final analysis, is a kind of aggregation promotion, mainly manifested as the combination of artificially low price control and supply restriction [11]. In live commerce, businesses rely on the platform's flow base to create a tense atmosphere and artificial phenomenon of short supply, which runs through three stages: early warm-up, middle empathy and late feedback [12]. For e-retailers, adopting the hunger marketing model can bring many advantages. First, by controlling retail price and total sales volume, the total profit of the supply chain is increased and the double marginalization effect is aggravated. Yu and Zhang (2018) studied the impact of the hunger marketing strategy on supply chain pricing, and coordinated the supply chain through a two-period pricing model [13]. Tolety (2016) studied hunger marketing, time-limited sales and cost optimization strategies of Xiaomi [14]. Chen (2016) studied the application analysis of hunger marketing in the mobile phone industry [15]. However, as a new strategy of live commerce, there are few studies on hunger marketing 
strategy as the preset background. As a new development trend, it is more meaningful to study the impact of the hunger marketing strategy adopted by live commerce on consumers' purchasing behavior.

The buying behavior of consumers can be divided into purported buying and impulsive buying [16]. Intentional purchase refers to the planned purchase behavior of consumers. Impulse buying behavior tends to be unplanned but is carried out because consumers are aroused by positive emotions and have an immediate desire to have [17] a particular item. Wells and Veena (2011) defined impulse buying as the consumer being spontaneous and temporarily out of control, and having a strong desire to buy. Impulse buying behavior is very common [18]. Relevant (2018) studies show that modern consumers clearly pay attention to hedonism and realizable consumption styles [19]. Impulse buying accounts for about $80 \%$ of product sales, and the sales of new products are basically impulse purchases [20]. Jiang and Zhao (2013) found that the images of goods, services, convenience and safety have a significant impact on consumers' intentional purchases, and a virtual experience can stimulate consumers' impulsive purchase behavior [21]. Compared with offline shopping, online shopping consumers, as a result of time and space constraints, showed more obvious characteristics of impulse buying, especially with regard to the process of a live business platform., Businesses take advantage of these tendencies to motivate consumers to make impulsive buying decisions, and push them further into impulse buying behavior. In combination with the merchant hunger marketing model in live commerce, this article defines impulse buying behavior as the consumer's strong and eager purchase behavior under the stimulation of external factors on the premise of the absence of any clear purchasing plan on behalf of the consumer.

The hunger marketing model is often used in traditional marketing, but it rarely gets attention under the background of live commerce with goods. However, under the marketing environment of limited time and limit, most consumers are more likely to engage in impulsive consumption behavior. In addition, the existing studies adopt a relatively independent and decentralized approach, that is, they only study related factors separately, such as store environment [22], promotion intensity [23], time scarcity [24], consumer trust [25], etc. Few studies integrate these interrelated concepts. Taking SOR as the theoretical basis, we established a model and set the research background in the case of hunger marketing strategy in the mode of live commerce to comprehensively explore the influence factors of external stimulus factors and internal mechanism on consumers impulse buying behavior. This paper enriches the research field of consumer behavior in the context of e-commerce, provides precise supplement for consumers to make impulsive behavioral decisions in the online shopping environment, and helps e-commerce platforms and enterprises to change their innovation mode and realize sustainable development of e-commerce platforms.

This paper is divided into the following parts: The first part is the introduction. The second part proposes a theoretical model and hypothesis research. The third part is questionnaire design and data collection, and the fourth part tests and analyzes the collected data. The fifth part analyzes the hypotheses and conclusions. The sixth part puts forward accurate suggestions on the sustainable development strategy of hunger marketing under the current e-commerce model and points out the limitations of this paper.

\section{Theoretical Basis and Hypothesis Research}

\subsection{Theoretical Basis of SOR}

The SOR (stimuli-organism-response) theory is a cognitive theory of psychology that studies human behavior by adding the intermediate process of "individual psychological activity" on the basis of "stimulus-response" theory, emphasizing the mediating role of individual physiological and psychological activities. The SOR theory holds that the behavioral decision-making (i.e., response) whereby consumers decide to approach or avoid comes not only from the attention to external environmental factors (i.e., stimulation), but also from the sensory cognition of consumers' internal state (i.e., organism). The 
SOR model is considered to be successful in explaining behavioral differences caused by various marketing stimuli and cognitive factors. The main advantage of the SOR model is that it is flexible and includes the opportunity to examine a variety of internal and external stimuli. The SOR theory is widely used to explain consumer behavior or consumer will, particularly based on the impact of external environmental characteristics on consumers' internal psychological state and behavioral response [26]. The SOR theory is widely used to explain consumer behavior or consumer will, especially based on the impact of external environmental characteristics on consumers' internal psychological state and behavioral response. Jing and Sung (2019) explored the effect of service recovery on customer behavioral intention in online shopping malls under the mediating effect of customer forgiveness based on the SOR model [27]. Hu et al., (2012) studied the influence of information content and information form on consumers' purchasing behavior under the mediation of channel mode through SOR theory [28].

Consumers' behavioral motivation is controlled by self-consciousness, and conscious cognition is the intermediary. When commodity browsers are stimulated by the external environment, they will rely on subjectivity to form a "cognitive structure". At this time, they do not act directly, but deliberately and actively obtain effective information from the stimulation process and consider whether to choose commodities, and then respond. "Stimulation" in the retail environment can often attract consumers' attention and cause changes in their psychological feelings. This stimulation is usually via external environmental factors, including marketing strategies and other objective effects; "Organism" is an individual's internal activity process. It is a cognitive process in which consumers consider themselves, their money and risk after receiving the information they see or hear; "Response" includes psychological and behavioral responses, that is, the decisions consumers will make after processing the information.

\subsection{Research Assumptions}

\subsubsection{Research Assumptions of Anchor Characteristics}

An e-commerce influencer is an important front in live commerce [29]. By virtue of a person's professionalism, popularity, interactivity and affinity, they interact with consumers in real time through live commerce platforms, serving as a bridge between businesses and consumers. Influencers help merchants to promote products and deliver product information and enhance their brand image. Meanwhile, as the executer of the hunger marketing strategy, e-commerce influencers help consumers to know more about products and stimulate consumer demand. Enthusiasm is based on the personality characteristics of the influencer, bringing consumers an enhanced shopping experience, and influencing their attitudes and bolstering the strength of the products they represent. They also enhance the scarcity of the product and add a sense of immediacy to the impending purchase. This is all designed to strengthen the perceived value of a product and guide consumers to make impulsive shopping decisions [30]. Zhang and Zhang (2021) pointed out that influencers play an important role in sales performance in network broadcasts, and categorized the characteristics of influencers into Internet celebrities' charm, entertainment and professional knowledge, confirming that these three characteristics have a positive impact on consumers' purchase intention [31]. Zhao and Wang (2021) divided influencer features into interactivity, authenticity, professionalism and popularity, and verified that influencer $=$ characteristics had a positive impact on consumers' perceived trust and perceived value from four dimensions, thus promoting their purchase intention [32]. Based on this, the following hypotheses are proposed:

Hypotheses 1 (H1). Anchor characteristics have a significant positive impact on consumers' perceived trust.

Hypotheses 2 (H2). Anchor characteristics have a significant positive impact on consumers' perceived value. 


\subsubsection{Hypothetical Research on Online Comment Factors}

As the carrier of information dissemination, online comments have attracted increasing attention from companies and consumers. The function of online comments not only reduces consumers' uncertainty about product quality and experience attributes [33], but also significantly affects the company's operational decisions and helps reshape business growth [34]. Combined with the characteristics of live commerce, this study defines online comments as real-time comments sent by consumers during live watching. The comments are displayed on the screen in the form of subtitles to each consumer who watches the live commerce, which provides help for the online interactions between businesses and consumers. It provides real-time answers to relevant information about products and services and creates a shared shopping experience. Online product reviews are a powerful source of information for consumers. Personal reviews help consumers reduce product uncertainty and imperfect product page information [35]. Online reviews provide consumers with the possibility of real quality on e-commerce platforms and play an important role in customer purchase decisions [36]. Qi (2021) built a research model for consumer acceptance of online comments based on the TAM model, which proved that the quantity and quality of online comments has a significant positive impact on purchase behavior [37]. Shen and Chang (2021) showed that online comments and customer experience are important factors affecting consumers' online purchase intentions [38]. Customer value plays an intermediary role in the relationship between them. Accordingly, the following assumptions are proposed:

Hypotheses 3 (H3). Online comments have a significant positive impact on consumers' perceived trust.

Hypotheses 4 (H4). Online comments have a significant positive impact on consumers' perceived value.

\subsubsection{Hypothesis Research on Logistics Service Quality}

Logistics services play an important role in the development of live commerce. It is not only the key link and basic guarantee of online shopping [39], but also the last link to complete the online transaction. Consumers are the direct service objects of logistics services. They not only pay attention to product quality and price, but also have a variety of logistics needs. Businesses need to integrate and optimize the allocation of resources in the market and improve the consumption experience to meet the personalized and differentiated logistics service needs of customers. Meeting the logistics service needs of consumers will help to improve the relationship quality between customers and businesses and enhance consumer satisfaction. Similarly, online shopping can enhance consumers perceived value by improving the quality of logistics services. When consumers have a pleasant shopping experience, the degree of perceived value will increase. There are concessions before sales and guarantees after sales, and consumers are more likely to have impulsive buying behaviors. Liang and Zhang (2016) believe that logistics services play an important positive role in consumers' psychological contract, and one of the key elements of this psychological contract is consumers' trust [40]. Liu (2021) used a regression model analysis method to verify that personalized logistics services can effectively enhance consumers' willingness to make repeat purchases under the intermediary influence of relationship quality [41]. At the same time, personalized logistics services also affect consumer satisfaction. In this process, consumer trust plays an intermediary role. Yan et al., (2020) divided the refined logistics service elements into reliability, responsiveness, timeliness and the attitude of distribution personnel, and verified the positive impact of the four elements on customer perceived value [42]. Accordingly, the following assumptions are proposed:

Hypotheses 5 (H5). Logistics service quality has a significant positive impact on consumers' perceived trust. 
Hypotheses 6 (H6). Logistics service quality has a significant positive impact on consumers' perceived value.

\subsubsection{Hypothesis Research on Promotion Incentive Information}

Promotional incentive information is used by e-commerce enterprises to publicize promotional activities and introduce product information before and during live commerce, especially to highlight the preferential strength of a price discount [43]. E-commerce merchants attract users by influencing consumers' sensitivity to price [44] so as to improve consumers' participation and purchasing power. Especially in the hunger marketing mode under the e-commerce platform, in order to induce consumers to buy specific goods immediately, the promotion incentive is often stronger than daily purchase activities, which directly affects the perceived trust, value and purchase intention of price sensitive consumers. The promotional incentive information can make consumers perceive the temptation of the promotion to save money, the richness of promotion commodity categories, quantities and styles, and the interest of participating in rush buying activities in the broadcast room, so as to encourage public participation and consumption enthusiasm. Through this shortterm stimulation tool, the broadcast room will form a shopping phenomenon of gathering shopping, which overcomes the wait-and-see mentality of consumers to a certain extent, strengthening consumers perceived trust with a rush buying atmosphere, thereby reducing perceived risks and eliminating pre-purchase doubts, and making impulse purchase decisions more likely. Prasilowati et al., (2021) believe that price promotion has a significant impact on customer satisfaction [45]. Chen (2021) pointed out that price promotion and gift promotion in promotion incentives can effectively improve consumers' perceived savings and reduce perceived risk, so as to enhance consumers' purchase intention [46]. Accordingly, the following assumptions are made:

Hypotheses 7 (H7). Promotion incentive information has a significant positive impact on consumers' perceived trust.

Hypotheses 8 (H8). Promotion incentive information has a significant positive impact on consumers' perceived value.

\subsubsection{Hypothetical Research on Promotion Time Limit}

As a marketing method, live commerce induces consumers to make immediate purchase decisions based on a certain amount of price discounts only available for a limited time. As one of the elements of the decision-making situation, time pressure plays a regulatory role in decision-making behavior [47]. In this short-term decision-making environment, under the atmosphere of exaggerating economic interests from businesses, consumers have a strong sense of time urgency, which affects consumers ability to obtain complete information and process the information in the process of evaluating the product. Instead, they pay more attention to the influencer's description of the items in question [48]. At the same time, shortened decision-making time leads to the impairment of consumers' cognitive functions, resulting in the perceived opportunity cost of "regret if you don't buy". According to the deadline effect, the closer to the end of the promotion, the stronger consumers' sense of urgency to buy. This "scarcity opportunity" urges consumers to convert potential purchase cognition into an obvious purchase opportunity, which not only ignores the purchase risk, but also emphasizes the acquisition of perceived benefits, resulting in positive perceived value.

Lu and Huang (2014) emphasized that the shorter the promotion duration, the stronger consumers' perception of opportunity cost and the higher their cognitive response to the perceived value of the promotion [49]. Hong (2021) pointed out that when online retailers promote products under the condition of a short time limit promotion and high time pressure, it increases the likelihood that consumers will make a decision to purchase [50]. Accordingly, the following assumptions are proposed: 
Hypotheses 9 (H9). The promotion time limit has a significant positive impact on consumers' perceived value.

\subsubsection{Research Hypothesis of Perceived Trust}

Trust is an important variable in the study of consumer behavior. It is generally regarded as a psychological state with positive expectations for the behavior or intention of others [51]. As a prerequisite for online consumers' purchase decision [52], consumer trust is described as a basic element of e-commerce, which can reduce the uncertainty of a purchase and help improve consumers' loyalty and acceptance. Lack of trust will lead to consumer doubt and thereby and have a negative impact on their purchase intention [53]. Live commerce is a real-time interactive mode, which contributes to consumers having a sense of subjectivity and intimacy in the interaction. It can be seen that the richer the information content, the more diverse the forms, the higher the timeliness, and the higher the trust of consumers. At the same time, consumers have the pleasure of perceived value based on their trust in this hunger marketing model. Feng and Lu (2020) believe that based on consumers' strong sense of social presence, the webcast environment meets consumers' demand for complete information and promotes consumers' trust in promotion links, which plays an intermediary role in consumers' impulse purchase decisions [54]. Therefore, the following assumptions are put forward:

Hypotheses 10 (H10). Perceived trust has a significant positive impact on consumers' impulse buying behavior.

\subsubsection{Research Hypothesis of Perceived Value}

Perceived value is widely used to predict users' adoption behavior. Product quality, service quality and perceived value have an important impact on customer satisfaction. As a key mechanism to shape these relationships, customer perceived value has become an important consideration in the use and interaction with social media [55]. Zeeithaml (1988) first defined customer perception as "the overall evaluation of product effectiveness based on customers' perception of product acceptance and giving" [56]. Bettman (1998) defined customer perceived value as "the value perceived or experienced by customers through the use of a service" [57]. In the time-limited marketing link of the e-commerce platform, perceived value can be regarded as the overall evaluation of product performance by weighing perceived revenue and perceived purchase cost. When consumers feel that the comprehensive evaluation of the economic preference of goods, logistics, after-sales service level and relevant useful information in the broadcast room is higher than their original expectation, it will produce positive perceived value and make them more likely to purchase the item in question. Wang et al. (2021) believe that promotional purchase restrictions, on the one hand, enhance perceived value by highlighting the scarcity of restricted goods, while on the other hand stimulating consumer excitement to satisfy their impulse purchase intention [58]. Accordingly, the following assumptions are proposed:

Hypotheses 11 (H11). Perceived value has a significant positive impact on consumer impulse buying behavior.

The above hypotheses, supported by the relevant literature, is explained and incorporated in the research model in Figure 1. 


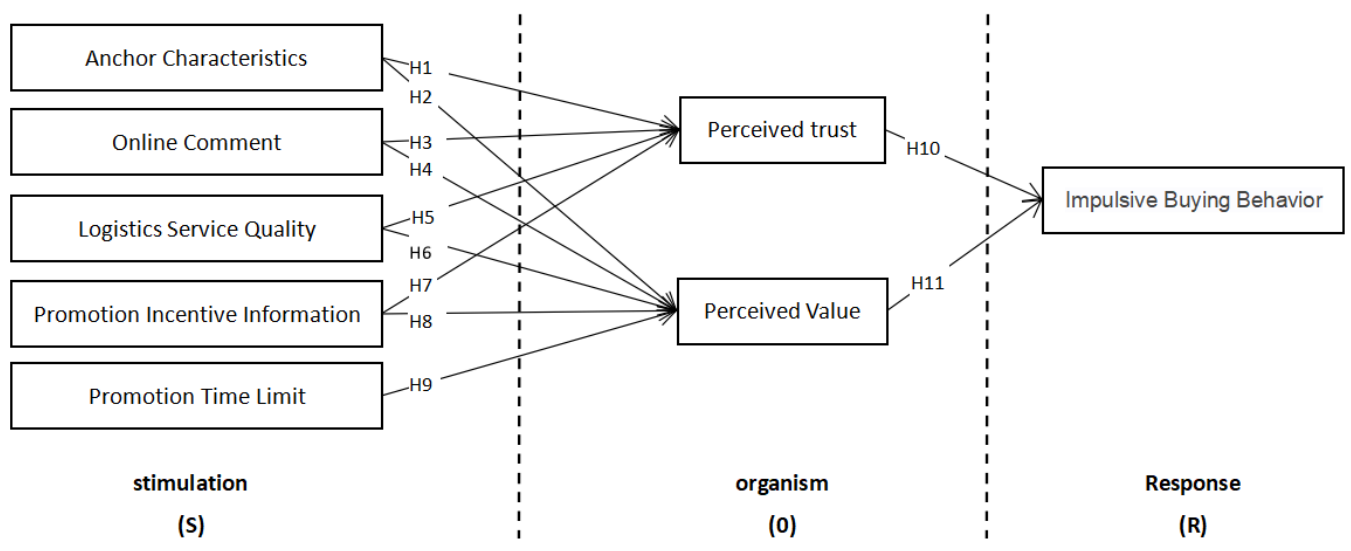

Figure 1. Research model.

\section{Questionnaire Design and Data Collection}

\subsection{Questionnaire Design}

In order to verify the assumptions that the researchers have with regard to consumers' online behavior, the questionnaire mainly includes two parts: the first part includes the survey participants' sample demographic characteristics such as gender, age, education, occupation, monthly average income, monthly average online consumption and an empty field where the person can add content, which might include their opinions or suggestions. The second part is the variables and the scale, including "anchor characteristics such as (AC)", "online comment (OC)" and "logistics service quality (LSQ)", "promotion incentive information (PII)", "promotion time limit (PTL)" and "perceived trust (PT)", "perceived value (PV)", "and impulse buying behavior (IBB)". The questionnaire measurement mainly refers to the design of 7-level Likert scale, ranging from (1) completely disagree to (7) completely agree. The detailed description of the questionnaire items is shown in Appendix A.

\subsection{Questionnaire Distribution and Data Collection}

In order to further ensure the quality of the formal questionnaire samples, the preliminary survey of the questionnaire was carried out. This link will make the questionnaire available in online and offline channels. Online distribution is distributed on major social platforms, while offline distribution is targeted at college students and residents in surrounding communities. In the pre-survey, a total of 80 questionnaires were collected, and five invalid questionnaires were excluded from the survey. The recovery rate of valid questionnaires was $93.8 \%$. Meanwhile, the data passed the skewness coefficient, kurtosis coefficient and reliability test.

The questionnaire was distributed mainly through online channels, primarily to consumers through various online social platforms. Data collection of the questionnaire lasted 75 days from 22 July to 4 October 2021, and a total of 593 users filled in the questionnaire. After screening, 533 valid questionnaires were screened out, with an effective recovery of $89.9 \%$.

\subsection{Sample Description}

The first part of the questionnaire fully reflects the sample division of 533 valid questionnaires. In terms of gender, males and females accounted for $47.8 \%$ and $52.2 \%$. Most of the respondents' ages are between 18-29 (52.9\%). 61.2\% of interviewees have a Bachelor's degree or junior college degree, and $18.9 \%$ of them have a Master's degree or higher, indicating that most of the interviewees have received a good education. By occupation, students were the major participants of this study $(35.3 \%)$. For further demographic information, see Table 1. 
Table 1. Demographic description.

\begin{tabular}{|c|c|c|c|c|}
\hline NO. & Characteristics & Category & Frequency & $\%$ \\
\hline \multirow{2}{*}{1} & \multirow{2}{*}{ Gender } & Male & 225 & 47.8 \\
\hline & & Female & 278 & 52.2 \\
\hline \multirow{5}{*}{2} & \multirow{5}{*}{ Age } & Less than 18 Years & 10 & 1.9 \\
\hline & & 18-29 Years & 282 & 52.9 \\
\hline & & 30-39 Years & 114 & 21.4 \\
\hline & & 40-49 Years & 48 & 9.0 \\
\hline & & $50+$ Years & 79 & 14.8 \\
\hline \multirow{4}{*}{3} & \multirow{4}{*}{ Highest Education } & Junior high school & 15 & 2.8 \\
\hline & & High school/technical secondary school & 91 & 17.1 \\
\hline & & Undergraduate & 326 & 61.2 \\
\hline & & Postgraduate & 101 & 18.9 \\
\hline \multirow{7}{*}{4} & \multirow{7}{*}{ Occupation } & Students & 188 & 35.3 \\
\hline & & Civil servant & 51 & 9.6 \\
\hline & & Teachers, doctors, banker & 56 & 10.5 \\
\hline & & Staff & 156 & 29.3 \\
\hline & & Retirees & 19 & 3.6 \\
\hline & & Operators & 31 & 5.8 \\
\hline & & Others & 32 & 6.0 \\
\hline \multirow{5}{*}{5} & \multirow{5}{*}{ Income } & 0-1000 Yuan & 76 & 14.3 \\
\hline & & 1001-3000 Yuan & 168 & 31.5 \\
\hline & & 3001-5000 Yuan & 139 & 26.1 \\
\hline & & 5001-7000 Yuan & 85 & 15.9 \\
\hline & & 7000 + Yuan & 65 & 12.2 \\
\hline \multirow{5}{*}{6} & \multirow{5}{*}{$\begin{array}{l}\text { Online Shopping } \\
\text { Consumption }\end{array}$} & Less than 500 Yuan & 284 & 53.3 \\
\hline & & 500-1500 Yuan & 147 & 27.6 \\
\hline & & 1501-3000 Yuan & 68 & 12.8 \\
\hline & & 3001-5000 Yuan & 23 & 4.3 \\
\hline & & $5000+$ Yuan & 11 & 2.1 \\
\hline
\end{tabular}

\section{Results and Discussion}

\subsection{Reliability Test}

A reliability test was used to judge the internal stability of questionnaire data and the reliability of measurement results.

Table 2 shows the mean value, standard deviation, Cronbach's $\alpha$ value and CITC value (the corrected term and the total correlation coefficient) of each item. It can be seen from the calculation results that the mean values of all variables are distributed between 4.33 and 5.12. The standard deviation, Cronbach's $\alpha$ value and CITC value of other variables were consistent with their reference standard values except for the PV1 of variables. These data prove that the questionnaire as a whole has a strong internal consistency. Considering that the value distribution of PV1 items in the perceived value is uneven and the CITC value is lower than the reference value of 0.5 , this study deletes the PV1 item to improve the reliability of the data.

\subsection{Validity Test}

A validity test, as an important means of testing, aims to verify the accuracy of the information reflected in the research content to the required measurement object. This validity test includes convergence validity and discriminant validity.

\subsubsection{Convergence Validity}

Convergence validity is used to check the consistency within the plane. The factor load of the standardized coefficient reflects the importance of the variable on the common factor, and the factor load of all variables ranges from 0.662 to 0.807 , all exceeding the threshold value 0.5 . Combined reliability (CR) refers to the reliability of a new variable composed of a combination of several other variables, reflecting whether each measurement item consistently explains the potential variable, and whether the CR value of each variable exceeds the recommended value of 0.7 . The AVE value of the mean variance extraction 
volume refers to the average variance of the interpretation level of potential variables to observed variables, and the AVE value of each variable that is distributed is between 0.5231 and 0.599 , all of which are more than 0.5 . It can be judged that the convergence validity of the sample data meets the standard.

Table 2. Reliability Checks.

\begin{tabular}{|c|c|c|c|c|c|c|c|}
\hline Latent Variables & Number of Items & Measuring Item & Mean & $\begin{array}{l}\text { Standard } \\
\text { Deviation }\end{array}$ & CITC & Cronbach's $\alpha$ after Deleting the Item & Cronbach's $\alpha$ \\
\hline \multirow{5}{*}{$\begin{array}{c}\text { Anchor } \\
\text { Characteristics } \\
\text { (AC) }\end{array}$} & \multirow{5}{*}{5} & $\mathrm{AC1}$ & 4.48 & 1.552 & 0.696 & 0.847 & \multirow{5}{*}{0.873} \\
\hline & & AC2 & 4.47 & 1.532 & 0.700 & 0.846 & \\
\hline & & AC3 & 4.34 & 1.471 & 0.713 & 0.843 & \\
\hline & & $\mathrm{AC} 4$ & 4.76 & 1.487 & 0.709 & 0.844 & \\
\hline & & AC5 & 4.72 & 1.529 & 0.680 & 0.851 & \\
\hline \multirow{5}{*}{$\begin{array}{l}\text { Online Comment } \\
\text { (OC) }\end{array}$} & \multirow{5}{*}{5} & OC1 & 4.81 & 1.482 & 0.597 & 0.823 & \multirow{5}{*}{0.842} \\
\hline & & OC2 & 4.87 & 1.470 & 0.711 & 0.792 & \\
\hline & & OC3 & 4.62 & 1.575 & 0.601 & 0.823 & \\
\hline & & OC4 & 4.63 & 1.513 & 0.673 & 0.813 & \\
\hline & & OC5 & 5.04 & 1.387 & 0.697 & 0.798 & \\
\hline \multirow{5}{*}{$\begin{array}{c}\text { Logistics Service } \\
\text { Quality } \\
\text { (LSQ) }\end{array}$} & \multirow{5}{*}{5} & LSQ1 & 4.85 & 1.482 & 0.665 & 0.868 & \multirow{5}{*}{0.881} \\
\hline & & LSQ2 & 4.90 & 1.519 & 0.737 & 0.851 & \\
\hline & & LSQ3 & 4.86 & 1.445 & 0.727 & 0.853 & \\
\hline & & LSQ4 & 4.90 & 1.455 & 0.725 & 0.854 & \\
\hline & & LSQ5 & 5.05 & 1.432 & 0.727 & 0.854 & \\
\hline \multirow{5}{*}{$\begin{array}{l}\text { Promotional } \\
\text { Incentive } \\
\text { Information } \\
\text { (PII) }\end{array}$} & \multirow{5}{*}{5} & PII1 & 4.33 & 1.579 & 0.631 & 0.850 & \multirow{5}{*}{0.865} \\
\hline & & PII2 & 4.55 & 1.574 & 0.695 & 0.834 & \\
\hline & & PII3 & 4.56 & 1.521 & 0.679 & 0.838 & \\
\hline & & PII4 & 4.60 & 1.539 & 0.698 & 0.833 & \\
\hline & & PII5 & 4.66 & 1.493 & 0.727 & 0.826 & \\
\hline \multirow{4}{*}{$\begin{array}{l}\text { Promotional } \\
\text { Time Limit } \\
\text { (PTL) }\end{array}$} & \multirow{4}{*}{4} & PTL1 & 4.70 & 1.387 & 0.631 & 0.770 & \multirow{4}{*}{0.815} \\
\hline & & PTL2 & 4.64 & 1.571 & 0.623 & 0.773 & \\
\hline & & PTL3 & 4.58 & 1.482 & 0.648 & 0.760 & \\
\hline & & PTL4 & 4.64 & 1.540 & 0.637 & 0.765 & \\
\hline \multirow{4}{*}{$\begin{array}{l}\text { Perceived Trust } \\
\text { (PT) }\end{array}$} & \multirow{4}{*}{4} & PT1 & 4.56 & 1.383 & 0.683 & 0.824 & \multirow{4}{*}{0.856} \\
\hline & & PT2 & 4.54 & 1.374 & 0.722 & 0.807 & \\
\hline & & PT3 & 4.71 & 1.377 & 0.677 & 0.826 & \\
\hline & & PT4 & 4.69 & 1.342 & 0.714 & 0.811 & \\
\hline \multirow{4}{*}{$\begin{array}{l}\text { Perceived Value } \\
\text { (PV) }\end{array}$} & \multirow{4}{*}{4} & PV1 & 4.80 & 2.192 & 0.403 & 0.827 & \multirow{4}{*}{0.742} \\
\hline & & PV2 & 4.93 & 1.331 & 0.684 & 0.619 & \\
\hline & & PV3 & 5.12 & 1.333 & 0.588 & 0.666 & \\
\hline & & PV4 & 4.89 & 1.387 & 0.619 & 0.646 & \\
\hline \multirow{5}{*}{$\begin{array}{l}\text { Impulse Buying } \\
\text { Behavior } \\
\text { (IBB) }\end{array}$} & \multirow{5}{*}{5} & IBB1 & 4.70 & 1.608 & 0.711 & 0.879 & \multirow{5}{*}{0.895} \\
\hline & & IBB2 & 4.98 & 1.534 & 0.752 & 0.869 & \\
\hline & & IBB3 & 4.83 & 1.562 & 0.765 & 0.866 & \\
\hline & & IBB4 & 4.95 & 1.525 & 0.771 & 0.865 & \\
\hline & & IBB5 & 4.97 & 1.482 & 0.709 & 0.879 & \\
\hline
\end{tabular}

\subsubsection{Discriminative Validity}

Discriminant validity is used to test the degree of difference between a given facet and other facets, and the observed facets can be distinguished from each other. As shown in Table 3, the AVE arithmetic square root values of the diagonal lines are much higher than the values of the relevant factors in the same column, indicating that each potential variable can be distinguished from each of the others by high discriminant validity.

Table 3. Discriminant validity.

\begin{tabular}{cccccccccc}
\hline & AVE & PTL & PII & LSQ & OC & AC & PT & PV & IBB \\
\hline PTL & 0.525 & $\mathbf{0 . 7 2 5}$ & & & & & & & \\
PII & 0.523 & 0 & $\mathbf{0 . 7 2 3}$ & & & & & \\
LSQ & 0.599 & 0 & 0 & $\mathbf{0 . 7 7 4}$ & & & & \\
OC & 0.523 & 0 & 0 & 0 & $\mathbf{0 . 7 2 3}$ & & & \\
AC & 0.578 & 0 & 0 & 0 & 0 & $\mathbf{0 . 7 6 1}$ & & \\
PT & 0.540 & 0 & 0.231 & 0.281 & 0.059 & 0.506 & $\mathbf{0 . 7 3 5}$ & \\
PV & 0.542 & 0.098 & 0.480 & 0.274 & 0.173 & 0.095 & 0.246 & $\mathbf{0 . 7 3 6}$ \\
IBB & 0.592 & 0.039 & 0.265 & 0.196 & 0.088 & 0.192 & 0.404 & 0.48 & $\mathbf{0 . 7 6 9}$ \\
\hline
\end{tabular}




\subsection{Modification of Structural Equation Model}

The structural equation model (SEM) is based on the covariance matrix and is designed to analyze the relationship between variables. The sample covariance matrix is equivalent to the model covariance matrix and determines whether the sample data and the hypothesis path analysis model match. In order to increase the comparability between variables, the model was modified in this study. It can be seen from the results that the standardized factor load of potential variables of each measurement model is distributed between 0.664 and 0.833 , which is higher than the standard value of 0.6 , and the SMC (square multiple correlation) value is distributed between 0.441 and 0.685 , higher than the standard value of 0.36. According to the revision suggestions in the analysis report, it can be seen that the PT3 measurement has a great correlation with PT1, PT2 and PT4, which should be removed according to the revision suggestions. The modified normalized path diagram and the fitting index of the structural equation model are shown in Figure 2 and Table 4.

Table 4. Structural equation model fit index.

\begin{tabular}{cccc}
\hline Fitness Index & Standard Values & Actual Value & Results \\
\hline Chi-square value(X2) & - & 1610.673 & Supported \\
Degrees of freedom (DF) & - & 594 & Supported \\
Significance level(P) & $<0.05$ & 0.000 & Supported \\
X2/DF & $<3$ & 2.934 & Supported \\
Fitness index (GFI) & $>0.9$ & 0.832 & Acceptable \\
Root mean square of approximate & $<0.08$ & 0.060 & Supported \\
error (RMSEA) & $>0.9$ & 0.891 & Acceptable \\
Comparative fitness index (CFI) & $>0.9$ & 0.844 & Acceptable \\
Standard fit index (NFI) & $>0.9$ & 0.891 & Acceptable \\
Increasing adaptation index (IFI) & $>0.5$ & 0.779 & Supported \\
Simplified benchmark adaptation & $>0.5$ & 0.725 & Supported \\
indicators (PNFI) & $>0.9$ & 0.882 & Acceptable \\
Reduced fit index (PGFI) & $>0.8$ & 0.808 & Supported \\
Noncanonical fit index (TLI) & $>200$ & 200 & Supported \\
Adjusted fit index (AGFI) & & &
\end{tabular}

The nonstandardized path coefficient is used to verify the existence of the influence relationship between variables, and the standardized path coefficient is used to judge the strength of the influence relationship between variables. According to the path coefficient data displayed by AMOS. using the maximum likelihood estimation method, the standardized and non-standardized path coefficients are plotted into tabulated statistics, and the results are shown in Table 5.

Table 5. Path coefficient test results.

\begin{tabular}{|c|c|c|c|c|c|c|c|}
\hline Hypothesis & Content & $\begin{array}{l}\text { Normalized Path } \\
\text { Coefficient } \\
\text { (Std.) }\end{array}$ & $\begin{array}{c}\text { Nonstandardized Path } \\
\text { Coefficient } \\
\text { (UStd.) }\end{array}$ & $\begin{array}{l}\text { Standard } \\
\text { Error } \\
\text { (S.E.) }\end{array}$ & $\begin{array}{l}\text { Critical Ratio } \\
\text { (C.R.) }\end{array}$ & $p$ & Results \\
\hline H1 & $\mathrm{PT}<-\mathrm{AC}$ & 0.497 & 0.429 & 0.050 & 8.632 & $* * *$ & Supported \\
\hline $\mathrm{H} 2$ & $\mathrm{PV}<-\mathrm{AC}$ & 0.092 & 0.076 & 0.044 & 1.740 & 0.082 & Not Supported \\
\hline $\mathrm{H} 3$ & $\mathrm{PT}<-\mathrm{OC}$ & 0.036 & 0.037 & 0.058 & 0.636 & 0.525 & Not Supported \\
\hline $\mathrm{H} 4$ & $\mathrm{PV}<-\mathrm{OC}$ & 0.173 & 0.169 & 0.058 & 2.923 & $* * *$ & Supported \\
\hline H5 & $\mathrm{PT}<-\mathrm{LSQ}$ & 0.229 & 0.284 & 0.051 & 5.530 & $* * *$ & Supported \\
\hline H6 & $\mathrm{PV}<-\mathrm{LSQ}$ & 0.275 & 0.249 & 0.050 & 4.942 & $* * *$ & Supported \\
\hline $\mathrm{H} 7$ & $\mathrm{PT}<-\mathrm{PII}$ & 0.224 & 0.208 & 0.052 & 3.977 & $* * *$ & Supported \\
\hline $\mathrm{H} 8$ & $\mathrm{PV}<-\mathrm{PII}$ & 0.480 & 0.426 & 0.057 & 7.469 & $* * *$ & Supported \\
\hline H9 & $\mathrm{PV}<-\mathrm{PTL}$ & 0.097 & 0.094 & 0.051 & 1.831 & 0.067 & Not Supported \\
\hline $\mathrm{H} 10$ & $\mathrm{IBB}<-\mathrm{PT}$ & 0.301 & 0.332 & 0.058 & 5.721 & $* * *$ & Supported \\
\hline H11 & $\mathrm{IBB}<-\mathrm{PV}$ & 0.412 & 0.477 & 0.063 & 7.629 & $* * *$ & Supported \\
\hline
\end{tabular}

Note: ${ }^{* * *} p<0.001 ; p>0.05$ (not significant). 


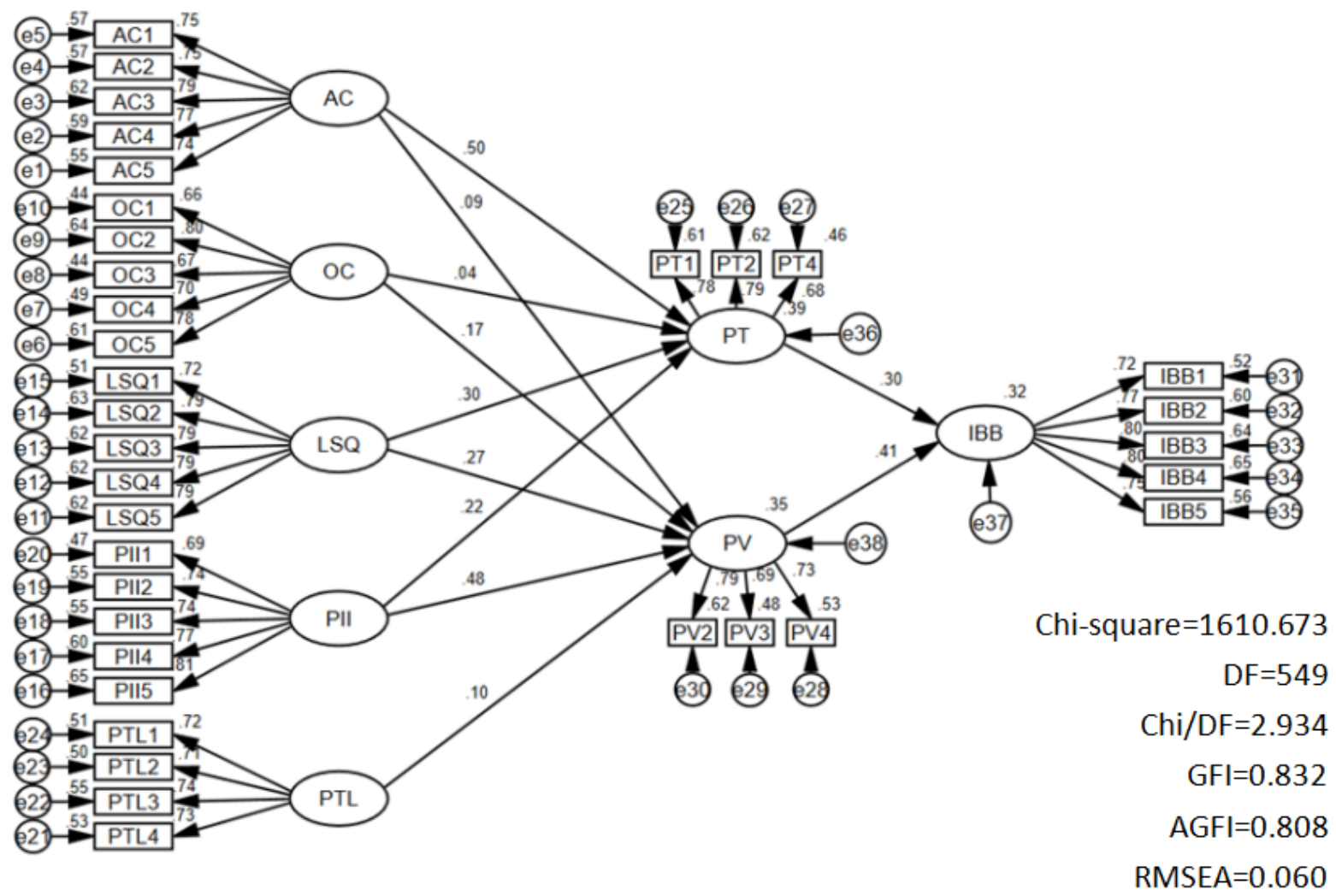

Figure 2. Normalized path coefficient diagram.

\section{Conclusions and Empirical Analysis}

According to the path coefficient test results of the research hypothesis model in Table 5, the test results and empirical analysis of this study can be interpreted as follows:

1. The influencer characteristics have a significant positive impact on consumers' perceived trust $(\gamma=0.497, p<0.001)$. Therefore, H1 was supported. This also confirms that in the hunger marketing mode, influencers provide comprehensive and professional explanations of product information and activity information with their rich professional knowledge and sales experience to bring consumers a sense of intimacy. They have established a bond of trust between consumers on platforms, products and services [59].

2. The effect of influencer characteristics on consumers' perceived value fails to reach a significant level $(\gamma=0.092, p=0.082)$. Thus, $\mathrm{H} 2$ was untenable. This may be because before the influencers explain the preferential content, the product links on the platform have more or less introduced the product information and created preferential intensity or created initial impressions [60], which makes the influencers have certain psychological expectations of consumers in the process of explaining. Therefore, the influencer factor is not obvious in consumers' determination of perceived value.

3. Online reviews have no significant effect on consumers' perceived trust $(\gamma=0.036$, $p=0.525)$. H3 was not assumed. There are two reasons for this: on the one hand, there are a large number of participants in the broadcast room and the scrolling speed of online comments is fast, making it difficult for consumers to capture useful information. On the other hand, due to the difficulty of supervision, chaos emerges in endless streams, and there are more malicious bad comments from competitive businesses in the comments, resulting in a mix of bad information. It is difficult for consumers to distinguish the quality with regard to real-time reviews, resulting in reduced trust in real-time review valence. 
4. Online comments have a significant positive effect on consumers' perceived value $(\gamma=0.173, p<0.001)$. Therefore, H1 was supported. Consumers are immersed in a strong sense of social presence by participating in real-time online reviews. Personal reviews also have a strong impact on consumers' perceived value and purchasing decisions. This effect is particularly pronounced when individual reviews help consumers resolve product uncertainties or contrast with aggregated information that is readily available on product pages [61].

5. Logistics service quality has a significant positive impact on consumers' perceived trust $(\gamma=0.229, p<0.001)$ and perceived value $(\gamma=0.275, p<0.001)$. H5 and H6 were supported. Faced with consumer demands for various logistics services, ecommerce enterprises can not only guarantee basic logistics services, but also launch other differentiated value-added services. This not only improves consumers' credit evaluation of online shopping, but also helps to reduce consumers' perceived risk and guarantee the promise of after-sales support [35].

6. Promotional incentive information has a significant positive impact on consumers' perceived trust $(\gamma=0.224, p<0.001)$ and perceived value $(\gamma=0.480, p<0.001)$. H7 and H8 were supported. Most of today's consumers are price-sensitive with utilitarian value appeals. Online promotions are favored by hedonistic consumers [62]. The promotion and incentive information of e-commerce can be fully interpreted in the warm-up process and marketing process, and a proper promotion strategy will win the trust of consumers. The activity intensity of goods makes consumers perceive the lure of promotional benefits, which not only deepens their sense of identity to the enterprise, but also effectively improves consumers' perceived value and increases the likelihood that they will make impulse purchase decisions.

7. The promotional time limit has no significant positive effect on consumers' perceived value $(\gamma=0.097, p=0.067)$. H9 was not accepted. In the broadcast room, the hunger marketing strategy will have a time limit on preferential products and create opportunities for scarcity in order to incite consumers to purchase in large quantities. However, it is generally seen that the frequency of live commerce and the number of product events by merchants have increased significantly compared with the past, which has increased the opportunities for consumers to snap up quantity restricted products, and the promotional time limit is not the only opportunity for them to purchase these particular items, leading consumers to postpone purchases indefinitely. In addition, the fact that consumers are busy will weaken their tendency to wait for time-limited discount purchases [63], and the perceived value level of the hunger marketing model will weaken.

8. Consumers' perceived trust $(\gamma=0.301, p<0.001)$ and perceived value $(\gamma=0.412$, $p<0.001$ ) both have a significant positive impact on impulse buying behavior. H10 and H11 were supported. Whether because the live commerce scene simulates the offline stores, or whether merchants and influencers comprehensive introduction of product and activity rule information [64] enhance trust, or whether it is because of the influence of other factors, it will have a certain impact on consumers' trust. It is because of consumers' trust in this kind of hungry marketing mode that consumers' complete demand for online shopping is met. At the same time, the rapid development of the e-commerce network shortens the space and time distance between products and consumers, and endows them with higher value. Compared the amount of time, energy and money, when consumers get caught up in the overall feelings referred to in the hunger marketing model, and particularly feel the urge to make a purchase because of time restrictions under the constraints of the perception of an opportunity cost, this generate a positive perception of an item's value, and the feasibility of the impulse buying behavior will be stronger. 


\section{Research Suggestions and Limitations}

\subsection{Research Suggestions}

From all the collected questionnaire information and the analysis of the research results, we can find that the consumer acceptance of the hunger marketing in live commerce is relatively high. However, some problems existing in some links in the purchase process will also affect consumers' continuous repurchase. In order to help the sustainable development of live commerce, we put forward the following suggestions for the shortcomings of the hunger marketing mode adopted by live commerce.

\subsubsection{Anchor}

The behavior of e-commerce anchors most directly affects consumers' awareness of product information and activity content. In recent years, e-commerce anchor has become a popular career which has a low threshold but high income, resulting in the uneven quality of live commerce anchors. Therefore, e-commerce platforms should hire anchors with a certain level of popularity, professional knowledge, and a good image and temperament. Meanwhile, in order to improve customer satisfaction, anchors should not only introduce product information and in detail on the live broadcast, but also possess other qualities that enable them to reply to customer questions accurately and in a timely manner, with emphasis on their positive interaction with consumers. If necessary, the mode of "professional anchor + popular flow" can be adopted to ensure the popularity of live commerce.

\subsubsection{Online Comments}

Online real-time comments are an important factor for consumers to integrate into the hunger marketing model. E-commerce merchants should attach importance to the interactions in the comment sections and actively respond to the questions found there. In order to attract more consumers to participate in live broadcasts, e-retailers can use the review section as a platform to enrich the form of activities add interactive links, so as to increase the purchase rate. In addition, businesses should also be vigilant and strengthen measures to reduce the occurrence of malicious fake reviews.

\subsubsection{After-Sales Service}

After-sales service quality has a significant impact on the performance of online retailers [65]. Ensuring after-sale service is a necessary measure to eliminate consumers' misgivings. Therefore, merchants should make wise measures, such as improving after-sales quality assurance security, adding seven-day return service without conditions attached, and adding complimentary freight insurance in order to enhance consumer confidence that they are having a worry-free purchase experience.

\subsubsection{Promotional Incentive Information}

The lower price and relevant preferential activities are often the things that consumers notice the most. However, due to the improper publicity of the enterprise in the early stage, many potential consumers do not receive the activity information, which in the loss of customers for the business. Therefore, businesses should promote through multiple channels that are widely spread through various ways to let consumers know the facts, improve the weight of livestreaming numbers, and create promotional policies. At the same time, high-quality live commerce incentives can help improve consumers' experience and increase their desire to buy. In the selection of products, businesses should be more strictly with the supply to ensure that product quality remains as the core priority. At the same time, they should ensure that the preferential policies are understandable and true, and make the price comparisons between live commerce platforms transparent. In the process of live commerce, they should try to increase the distribution of discounts and coupons for goods, and adjust the frequency of time-limited promotions according to the attributes of the goods [66]. When necessary, businesses can meet consumers' demand for "price 
protection", establish a good brand image, improve pre-sale standards, improve after-sales mechanisms, and protect the interests of the platform, of the sellers, and of the consumer.

\subsubsection{Promotion Time Limit}

The setting of time limits for promotions is the most controversial aspect of e-commerce platforms. The length of promotion time will directly affect consumers' buying mentality. Setting time limits is the hard part of buying campaigns. If it lasts too long, consumers will think that waiting is a waste of their time. Too short a buying time will give people a sense of urgency. In addition, we found that the frequency settings of live commerce events also need to be optimized. The excessive frequency of live commerce of restricted goods will reduce consumers' perceived value of the item in question. However, if the frequency is low, consumers will be irritated because they cannot purchase the goods in question. Accordingly, the improvement of the promotional time limit can be carried out in the following manner. First, merchants should set the expected sales volume according to the expected response. Second, a fixed start time should be set, and a timely notice of the time of buying should be given to the consumer in order to avoid the loss of customers. Third, a promotional buying time should be set so that consumers can receive information and consider the potential purchase rationally on the basis of the same acquisition process of perceived pleasure.

\subsubsection{Promotional Program Setting}

In order to enhance their popularity and gain more exposure, businesses will ask consumers to complete some tasks during the live commerce event in order to qualify to purchase of the item being advertised. Too many routines and tedious steps in this process will reduce consumers' purchasing motivation. It is suggested that direct broadcast promotion procedures be simplified. Businesses should establish the connection between consumers and brands by designing reasonable promotional programs to ensure the consumers' purchasing enthusiasm [67], so as to increase the likelihood that the customer will return to make future purchases, while at the same time addressing the concerns of consumer groups.

\subsection{Research Limitations}

Despite our new findings and recommendations for the sustainability of live commerce, this article has some limitations. We used online questionnaires, and the arbitrary attitudes of some respondents may have a certain influence on the research results. In the future, we might consider adding offline filling channels in order to help researchers understand consumers' intuitive feelings about e-commerce live broadcasts in person and thereby draw more comprehensive research conclusions. In addition, there may be limitations in the selection of external stimulus influencing factors. In the future, we will try to consider more factors.

Author Contributions: Z.Z. presented the idea. N.Z. wrote the first draft of this paper. J.W. revised the first draft. Z.Z. was involved in the literature review section and data collection along with N.Z. and J.W. Data analysis was done by the joint effort of N.Z. and J.W. All authors have read and agreed to the published version of the manuscript.

Funding: This research was funded by the Program for the Philosophy and Social Sciences Research of Higher Learning Institutions of Shanxi, grant number 2020 W013 and the educational reform Innovation Programs of Higher Education Institutions in Shanxi, grant number J2021041.

Institutional Review Board Statement: Not applicable.

Informed Consent Statement: Not applicable.

Data Availability Statement: Not applicable.

Conflicts of Interest: The authors declare that they have no conflict of interest. 


\section{Appendix A}

Table A1. Questionnaire item.

\begin{tabular}{|c|c|c|}
\hline Latent Variables & Serial Number & Measuring Item \\
\hline \multirow{5}{*}{$\begin{array}{l}\text { Anchor Characteristics } \\
\text { (AC) }[68,69]\end{array}$} & AC1 & $\begin{array}{l}\begin{array}{l}\text { When watching the live commerce, I think the anchors will respond to my questions in a } \\
\text { timely manner. }\end{array}\end{array}$ \\
\hline & $\mathrm{AC} 2$ & $\begin{array}{l}\text { The communication and interaction of the anchors made me feel that the live commerce } \\
\text { marketing activity was very valuable. }\end{array}$ \\
\hline & AC3 & I think the product information recommended by anchors for me is authentic and credible. \\
\hline & AC4 & $\begin{array}{c}\text { Through the direct experience of the anchor to the product, I deepened my understanding of } \\
\text { the product. }\end{array}$ \\
\hline & AC5 & $\begin{array}{l}\text { I think anchors are familiar with the product and have professional knowledge, so they can } \\
\text { explain clear and accurate activity information. }\end{array}$ \\
\hline \multirow{5}{*}{$\begin{array}{c}\text { Online } \\
\text { Comments } \\
\text { (OC) } \\
{[70-72]}\end{array}$} & OC1 & I take the initiative to read the feedback of the online comments in the studio. \\
\hline & OC2 & I choose to buy items with a high number of real-time reviews. \\
\hline & OC3 & I tend to be drawn to extreme (positive or negative) real-time comments. \\
\hline & OC4 & I can share my shopping tips with other customers through real-time online reviews. \\
\hline & OC5 & The content of real-time product reviews has an impact on my purchase decision. \\
\hline \multirow{5}{*}{$\begin{array}{l}\text { Logistics Service Quality (LSQ) } \\
\text { [73] }\end{array}$} & LSQ1 & $\begin{array}{l}\text { The timely and accurate processing of orders on e-commerce platforms encourages me to } \\
\text { snap up goods. }\end{array}$ \\
\hline & LSQ2 & $\begin{array}{l}\text { Merchants offer value-added services such as "seven-day no-excuses returns" and "instant } \\
\text { refunds" to encourage me to snap up goods. }\end{array}$ \\
\hline & LSQ3 & $\begin{array}{l}\text { If the logistics company cooperating with the merchant can promise to deliver the goods on } \\
\text { the scheduled time, I will consider snapping up the goods. }\end{array}$ \\
\hline & LSQ4 & $\begin{array}{c}\text { When the distribution range of logistics outlets meets my needs, I will consider } \\
\text { buying goods. }\end{array}$ \\
\hline & LSQ5 & $\begin{array}{l}\text { When the e-commerce platform can timely deal with my return or replacement } \\
\text { requirements, I will consider buying goods. }\end{array}$ \\
\hline \multirow{5}{*}{$\begin{array}{l}\text { Promotional; Incentive Information } \\
\text { (PII) } \\
{[48,74]}\end{array}$} & PII1 & $\begin{array}{l}\text { I will always pay attention to the promotional prices and coupon information released in the } \\
\text { live commerce. }\end{array}$ \\
\hline & PII2 & When buying goods, I like to buy promotional goods in the broadcast room. \\
\hline & PII3 & Livestreaming promotions allow me to get a more reasonable consumer price. \\
\hline & PII4 & The price discount in the broadcast room makes me feel very generous. \\
\hline & PII5 & The buying in the studio makes me feel more affordable. \\
\hline \multirow{4}{*}{$\begin{array}{l}\text { Promotion Time Limit } \\
\text { (PTL) } \\
{[75]}\end{array}$} & PTL1 & I feel that the sale time of the broadcast room is usually relatively short. \\
\hline & PTL2 & I feel like I have less time to decide if I want to buy something that's on sale live. \\
\hline & PTL3 & I feel like I'm snapping up sales right before the deadline. \\
\hline & PTL4 & $\begin{array}{l}\text { The closer I get to the end of a limited-time sale, the time pressure pushes me to buy as } \\
\text { quickly as possible. }\end{array}$ \\
\hline \multirow{4}{*}{$\begin{array}{c}\text { Perceived Trust } \\
\text { (PT) } \\
{[76,77]}\end{array}$} & PT1 & I think e-commerce live commerce platforms are trustworthy. \\
\hline & PT2 & I think the promises made by e-commerce platforms are reliable. \\
\hline & PT3 & $\begin{array}{l}\text { If there is a problem with the product, I believe the merchant will try his best to provide me } \\
\text { with a solution. }\end{array}$ \\
\hline & PT4 & $\begin{array}{l}\text { I think e-commerce platforms can provide enough commodity information and } \\
\text { quality services. }\end{array}$ \\
\hline \multirow{4}{*}{$\begin{array}{l}\text { Perceived Value } \\
\text { (PV) } \\
{[78]}\end{array}$} & PV1 & I think the products recommended in the e-commerce live commerce just meet my needs. \\
\hline & PV2 & The sales promotion makes me feel economical. \\
\hline & PV3 & When I participate in a sale, I feel good about getting a good deal. \\
\hline & PV4 & I feel it's very cost-effective to snap up sales. \\
\hline \multirow{5}{*}{$\begin{array}{l}\text { Impulse Buying Behavior (IBB) } \\
\text { [79] }\end{array}$} & IBB1 & $\begin{array}{l}\text { When I watch the livestream of e-commerce, I often buy something that I didn't intend } \\
\text { to buy. }\end{array}$ \\
\hline & IBB2 & $\begin{array}{l}\text { When I watch the live commerce, I often find some goods I want to buy that are not in } \\
\text { my plan. }\end{array}$ \\
\hline & IBB3 & In the flash sale, I will have a strong desire to buy goods. \\
\hline & IBB4 & I have a sudden urge to buy something during a flash sale. \\
\hline & IBB5 & After reading the preferential content of the product, I have a great possibility to buy. \\
\hline
\end{tabular}




\section{References}

1. Gong, X.X.; Ye, Z.L.; Liu, K.; Wu, N. The effects of live platform exterior design on sustainable impulse buying: Exploring the mechanisms of self-efficacy and psychological ownership. Sustainability 2020, 12, 2406. [CrossRef]

2. Geng, X.R.; Hao, Z.R. E-commerce direct marketing system architecture from the perspective of retail digital transformation. J. Commer. Econ. 2021, 13, 79-82.

3. Xia, S. Research on problems and countermeasures of e-commerce direct broadcast with goods marketing model. Log. Eng. Manag. 2021, 43, 76-79.

4. Huang, M.X.; Ye, Y.X.; Wang, W. The interaction effect of broadcaster and product type on consumers' purchase intention and behaviors in livestreaming shopping. Nankai Bus. Rev. 2021. Available online: https:// kns.cnki.net/kcms/detail/12.1288.F.2021 0915.0954.002.html (accessed on 5 January 2022).

5. Yan, X.X.; Dong, Y.H.; Zhang, M.M.; Qiao, J. Research on the impact of live broadcasting on consumers' buying behaviorintermediate by perceived value. Price Theor. Pract. Mag. House 2021, 6, 137-140.

6. Liu, Y.; Hong, X.L.; Feng, H. Website attributes in urging online impulse purchase: An empirical investigation on consumer perceptions. Decis. Support. Syst. 2013, 55, 829-837. [CrossRef]

7. Zhen, Q.D. Research on the influence of live streaming goods interactivity on consumers' cross-purchase intention. Pop. Stan. 2021, 11, 140-142.

8. Zhang, Y.J. Defects of traditional marketing model and new consumer experience requirements in the context of "new retail". J. Financ. Res. 2018, 2, 82-86. [CrossRef]

9. Sun, Y. Analysis of impulsive buying behavior in live broadcast scenarios. Educ. Reform. Dev. 2020, 2, 147-152. [CrossRef]

10. Guan, P.C.; Xiang, Y. On the guiding effect of hunger marketing strategy on consumer behavior. J. Commer. Econ. 2016, 4, 53-55.

11. Feng, H.; Fu, Q.; Zhang, L. How to launch a new durable good: A signaling rationale for hunger marketing. Int. J. Ind. Organ. 2020, 70, 102621. [CrossRef]

12. Zhang, Z.H.; Qiu, Y.S. Analysis on the marketing model of Douyin Live Broadcast with goods hungry. Mark. Mod. 2021, 3, 44-46.

13. Yu, L.l.; Zhang, J.Z. A two-period pricing model with hunger marketing strategy. J. Model. Manag. 2018, 13, 81-100. [CrossRef]

14. Tolety, R.K. Hunger Marketing, Flash sale and cost optimization strategy of Xiaomi inc.-Setting a new trend through etailing. Int. J. Res. Financ. Mark. 2017, 7, 182-185.

15. Chen, Q.Y. The Analysis of application of huger marketing in China's mobile phone industry. Sci. Innov. 2016, 4, 117-121. [CrossRef]

16. Liu, Y.; Li, Q.; Yin, M. Research on the influence of webcast shopping features on consumer buying behavior. Soft. Sci. 2020, 34, 108-114.

17. Rook, D.W.; Fisher, R.J. Normative influences on impulsive buying behavior. J. Consum. Res. 1995, 22, 305-313. [CrossRef]

18. Wells, J.D.; Parboteeah, V.; Valacich, J.S. Online Impulse Buying: Understanding the interplay between consumer impulsiveness and website quality. J. Assoc. Inf. Syst. 2011, 12, 32-56. [CrossRef]

19. Umair, A.; Peng, H.; Muhammad, K.K.; Chen, Y.; Zubair, A. Factors affecting online impulse buying: Evidence from Chinese social commerce environment. Sustainability 2018, 10, 352.

20. Lu, X.M.; Xue, Y.J. Analysis on the influencing factors of impulsive buying behavior. J. Bus. Res. 2011, 7, 50-52.

21. Jiang, C.; Zhao, H.X. B2C online store image, consumer perception and purchasing behavior. Res. Financ. Econ. Issues 2013, 10, $116-122$.

22. Naratama, I.M.; Rahyuda, I.K. Study of influence of store environment on impulse buying tendency. Russ. J. Agric. Socio-Econ. Sci. 2018, 82, 161-170. [CrossRef]

23. Carunia, M.F.; Maria, F. The effects of sales promotion, attractiveness of internet advertising, and website quality on impulse buying of consumers of Tokopedia in Indonesia. Int. J. Manag. Ent. Dev. 2021, 20, 34-48.

24. Li, C.X.; Wang, Y.T.; Lv, X.Y.; Li, H. To buy or not to buy? The effect of time scarcity and travel experience on tourists' impulse buying. Ann. Tour. Res. 2021, 86, 103083. [CrossRef]

25. Zhao, J.D.; Huang, J.S.; Su, S. The effects of trust on consumers' continuous purchase intentions in C2C social commerce: A trust transfer perspective. J. Retail. Consum. Serv. 2019, 50, 42-49. [CrossRef]

26. Jacoby, J. Stimulus-Organism-Response reconsidered: An evolutionary step in modeling (consumer) behavior. J. Consum. Psychol. 2002, 12, 51-57. [CrossRef]

27. Jing, W.; Sung, K.Y. A Study on the effect of service recovery through mediating customer forgiveness on customer behavior intention of online shopping mall-Based on the SOR model. J. Korean Soc. Qlty Manag. 2019, 47, 615-630.

28. Hu, H.Q.; Yan, J.Y.; Xu, L. Information richness, purchasing cost, channel mode and consumer purchasing behavior. Manag. Rev. 2012, 24, 80-88.

29. Lin, Z.H. The Influence of network broadcast information characteristics on impulsive buying: Based on the mediating role of flow experience. J. Commer. Econ. 2021, 14, 75-78.

30. Zhao, D.W.; Feng, J.X. The impact of characteristics of e-ommerce anchor as a key opinion leader on consumers' purchase intention. Commer. Res. 2021, 4, 1-9.

31. Zhang, Z.; Zhang, G.Q. Research on the Influences of anchors on webcast sales-Empirical test based on consumer questionnaire. Logist. Sci.-Tech. 2021, 44, 53-56.

32. Zhao, B.G.; Wang, Y.F. The influence of e-commerce anchor characteristics on consumers' purchase intention. Comm. Res. 2021, 1, 1-6. 
33. Yan, X.; Han, X.H. Optimal pricing and remanufacturing entry strategies of manufacturers in the presence of online reviews. Ann. Oper. Res. 2021, 1, 1-34. [CrossRef]

34. Jain, P.K.; Pamula, R.; Srivastava, G. A systematic literature review on machine learning applications for consumer sentiment analysis using online reviews. Comput. Sci. Rev. 2021, 41, 100413. [CrossRef]

35. Prasad, V.; Anja, L. The effect of individual online reviews on purchase likelihood. Market. Sci. 2021, 40, 708-730. [CrossRef]

36. Wu, X.I.; Liao, H.C. Learning judgment benchmarks of customers from online reviews. Or Spectr. 2021, 43, 1125-1157. [CrossRef]

37. Qi, Z.C. Analysis of the effect of online reviews on consumer intention. Front. Econ. Manag. 2021, 2, 90-98. [CrossRef]

38. Shen, C.C.; Chang, Y.R. Exploring the relationship among online review, perceived barriers, customer experience, and purchase intention of online booking consumers customer value as a mediator. J. Tour. Hosp. 2021, 10, 1-14.

39. Liu, Z.Y.; Yin, L.J.; Yuan, L.N. Research on the impact of logistics service factors on consumers' online shopping intention based on structural equation modeling. J. Math. Pract. Theory 2019, 49, 34-42.

40. Liang, W.; Zhang, W. Study on influence of logistics service involvement and perceived service quality on consumer psychological contract. J. U. Financ. Econ. 2016, 29, 68-74.

41. Liu, L. Analysis of the impact of personalized logistics services on consumers' repeated consumption intentions under the B2C model. J. Comm. Econ. 2021, 1, 115-118.

42. Yan, X.X.; Qiao, J.; Liu, X.M. Research on refined logistics service of fresh products under the background of new retail-Based on customer online repurchase willingness analysis. Price Theory Pract. 2020, 12, 111-114.

43. Yang, X.C.; Zhang, L. Research on the long-term effects of e-commerce promotions-An empirical study of t-mall consumers. J. Technol. Econ. Mana. 2020, 6, 36-41.

44. Zhang, H.; Li, L.; Zhu, X.Z.; He, X. Online shopping platform optimal price promotion strategy: Price discount or cash coupon? Chinese J. Mana. Sci. 2021. [CrossRef]

45. Prasilowati, S.L.; Suyanto, S.; Safitri, J.; Wardani, M.K. The impact of service quality on customer satisfaction: The role of price. J. Asian Financ. Econ. Bus. 2021, 8, 451-455.

46. Chen, K.W. Research on influence of online promotion type on consumer purchase intention. Mark. Wkly. 2021, $34,82-85$.

47. Cui, Y.Y.; Kim, S.S.; Kim, J.K. Impact of preciseness of price presentation on the magnitude of compromise and decoy effects. J. Bus. Res. 2021, 132, 641-652.

48. Ye, J.; Hu, C.L. The impact of live streaming time-limited promotion and anchor trust on consumers' clothing purchasing behavior. J. Silk 2021, 58, 57-67.

49. Lu, C.B.; Huang, C.F. The influence mechanism of Time pressure with need for cognitive closure on undoing regrets arising in decision-making of sales promotion. J. Bus. Manag. 2014, 36, 145-158.

50. Hong, R. Online flash sales product pricing strategy under time pressure. J. Wld. Sci. Res. 2021, 7, 376-382.

51. Rousseau, D.M.; Sitkin, S.B.; Burt, R.S.; Camerer, C. Introduction to special topic forum: Not so different after all: A cross-discipline view of trust. Acad. Manag. Rev. 1998, 23, 393-404. [CrossRef]

52. Anas, H.; Tony, W.; Asmai, I.; Putra, E.C. Consumer trust as the antecedent of online consumer purchase decision. China Inform. 2021, 12, 145.

53. Fan, M.; Ammah, V.; Dakhan, S.A.; Liu, R.; Mingle, M.N.; Pu, Z.J. Critical factors of reacquainting consumer trust in e-commerce. J. Asia Fbt. Econ. Bus. 2021, 8, 561-573.

54. Feng, J.; Lu, M. The empirical research on impulse buying intention of live marketing in mobile internet. Era. Soft Sci. 2020, 34, 128-133.

55. Hossain, U.M.U.; Ishraq, J.; Hussam, A.H.; Abdul, H.A.B.; Abdul, L.A.S. Does quality stimulate customer satisfaction where perceived value mediates and the usage of social media moderates? Heliyon 2020, 6, E05710.

56. Zeithaml, V.A. Consumer perceptions of price, quality, and value: A means-end model and synthesis of evidence. J. Mark. 1988, 52, 2-22. [CrossRef]

57. Bettman, J.R.; Luce, M.F.; Payne, J.W. Constructive consumer choice processes. J. Consum. Res. 1998, 25, 187-217. [CrossRef]

58. Wang, G.C.; Liu, W.J.; Wang, X.F. A situational study on the role of promotion purchase restriction under different promotion types: From the perspective of framing effect theory. Nankai. Bus. Rev. Int. 2021. Available online: http://kns.cnki.net/kcms/ detail/12.1288.F.20210629.1600.002.html (accessed on 5 January 2022).

59. Han, X.Y.; Xu, Z.L. Impacts of e-commerce anchor attributes on consumers' willingness to buy online: Research based on the grounded theory. Fgn. Econ. Manag. 2020, 42, 62-75.

60. Meng, Y.; Xie, H.T. Research on Preheating marketing of double-11 e-commerce platforms under entertainment fatigue. Log. Eng. Manag. 2020, 42, 98-100.

61. Kao, C.K.; Chen, Z.N.; Lin, P.J. Effect of online shopping credit evaluation on customer purchase risk: Logistics service as a mediator. Am. J. Theor. Appl. Bus. 2021, 7, 16-29. [CrossRef]

62. Narayanaswamy, R.; Heiens, R.A. Online sales promotion in hedonic versus utilitarian product categories. Int. J. Electron. Mark. Retail. 2018, 9, 77-88. [CrossRef]

63. Mao, Z.F.; Yu, S.Q.; Li, H.; Yuan, Y.Y. The time-limited discount pricing decision considering consumer demand transfer. Syst. Eng. Theory Pract. 2021, 41, 3232-3248.

64. Yang, N. The influence mechanism of web celebrity live broadcast on consumers' brand attitude. J. Cent. Univ. Financ. Econ. 2021, $2,118-128$ 
65. Liu, Y.; Gan, W.X.; Zhang, Q. Decision-making mechanism of online retailer based on additional online comments of consumers. J. Retail. Consum. Serv. 2020, 59, 102389. [CrossRef]

66. Jaiswal, B.; Saba, N.U. An Analytical study of behavioural response to sales promotion offers: With special reference to apparels. Int. J. Manag. IT Eng. 2019, 9, 79-88.

67. Jones, J.M. Non-Price sales promotion impact and moderator role. J. Promot. Manag. 2019, 25, 861-889. [CrossRef]

68. Harikesh, S.N.; Puneet, M.; Tulikaa, B. Asymmetric social interactions in physician prescription behavior: The Role of opinion leaders. J. Mark. Res. 2010, 47, 883-895.

69. Echchakoui, S. An analytical model that links customer-perceived value and competitive strategies. J. Mark. Anal. 2018, 6, 138-149. [CrossRef]

70. Chiou, C. Should a company have message boards on its websites. J. Interact. Mark. 2003, 17, 50-61. [CrossRef]

71. Park, D.H.; Lee, J.; Han, I. The effect of on-line consumer reviews on consumer purchasing intention: The moderating role of involvement. Int. J. Electron. Comm. 2007, 11, 125-148. [CrossRef]

72. Zhao, H.X.; Cai, Z.H.; He, S. The relationship between online merchandise displaying, online interaction and impulsive buying based on virtual tactility. Chin. J. Manag. 2014, 11, 133-141.

73. Mentzer, J.T.; Flint, D.J.; Hult, G.T.M. Logistics service quality as a segment-customized process. J. Mark. 2001, 65, 82-104. [CrossRef]

74. Payne, J.; Bettman, J.; Luce, M.F. When time is money decision behavior under opportunity cost time pressure. Organ. Behav. Hum. Decis. Processes 1996, 66, 131-152. [CrossRef]

75. Lu, C.B.; Qin, Q.X.; Lin, Y.Y. Cognitive mechanism in consumer decision-making under conditions of deceptive promotion: An Empirical research based on time pressure and overconfidence. Nankai Bus. Rev. 2013, 16, 92-103.

76. Alalwan, A.A.; Dwivedi, Y.K.; Rana, N.P. Factors influencing adoption of mobile banking by Jordanian bank customers: Extending UTAUT2 with trust. Int. J. Inform. Manag. 2017, 37, 99-110. [CrossRef]

77. Huang, S.H.; Xiao, J.C.; Jin, Y.N. Study on the influencing factors of consumers' continuous buying intention on social e-commerce platform based on S-O-R theory. Soft Sci. 2020, 34, 115-121.

78. Liu, J.; Zou, Y.J.; Liu, Z.X. Analysis of influencing Factors of Consumers' purchase intention in E-commerce live Broadcast based on SEM Model. Stat. Decis. 2021, 37, 94-97.

79. Adelaar, T.; Chang, S.; Lancendorfer, K.M.; Lee, B.; Morimoto, M. Effects of media formats on emotions and impulse buying intent. J. Int. Technol. 2003, 18, 247-266. [CrossRef] 